Beyond 'Between Two Cultures': micro processes of racialised and gendered positioning of South Asian and Muslim girls in an ‘everyday’ British multicultural school context

Veena Meetoo

Thomas Coram Research Unit, Department of Social Science, UCL Institute of Education, London, UK

Contact details: UCL Institute of Education, 20 Bedford Way, London WC1H OAL, veena.meetoo@ucl.ac.uk

Veena Meetoo is a Research Officer at the Thomas Coram Research Unit, UCL Institute of Education. Her research interests focus on the intersections of 'race', gender, migration, and minority ethnic young people, particularly for South Asian and Muslim girls, looked after children and separated child migrants. 


\title{
Beyond 'Between Two Cultures': micro processes of racialised and gendered positioning of South Asian and Muslim girls in an ‘everyday’ British multicultural school context
}

\begin{abstract}
This article reports on a case study exploring the social positioning and identities of South Asian and Muslim girls in one British inner city secondary school. The analysis is situated within the context of 'everyday multiculturalism', a framework which provides a lens on racialized and gendered encounters in the school context. Whilst their experiences were marked by exclusions, bullying and racialized, gendered and religious hierarchies, and typical processes of Othering, this appeared against the contradictory backdrop of the 'warmth' of multiculturalism and the silence of racism. Their experiences were therefore complex and signals the need to move beyond the discourse of the melodrama of South Asian girlhood, commonly depicted in dominant wider discourses in the form of 'between two cultures', towards a more nuanced understanding of the issues encountered in the everyday multicultural contexts of British schools marked by micro processes of racialized and gendered positioning
\end{abstract}

Keywords: South Asian Muslim girls, social positioning, 'race', racism, gender, 'everyday' multiculturalism 


\section{Introduction}

The 'between two cultures' discourse, that is, being positioned as neither 'east' (i.e. the traditions of family and community) nor 'west' (i.e. the liberal values of wider British society) (Watson 1977; Ghuman 2003), has been commonly employed in the British context for understanding the home lives of South Asian girls. Important counter voices from feminist scholars have emerged over the years, heavily criticizing such representations for feeding into 'melodramatic constructions' of South Asian

girls as possessing limited agency because of parental restrictions and cultural expectations (Puwar 2003; Ahmad 2003). Within such representations South Asian females are typically constructed as passive, quiet and in need of being saved from 'uncivilised' patriarchal culture (Shain 2003). The data discussed in this paper contributes to this body of work by offering a further lens on the identities of South Asian girls through a focus on the mundane, 'unspectacular' everyday interactions in a multicultural school site. A focus on the everyday multicultural school context provides an understanding of the experiences of South Asian girls that are manifested in everyday interactions with other students. This paper explores how through such encounters in schools and micro processes in action, racialised and gendered positions are reproduced and remade.

\section{South Asian girls and the dominant 'Between two cultures' discourse}

The 1970s was characterized by the overriding presumption that South Asian girls in the UK were situated 'between two cultures'. It is then unsurprising that literature on South Asian girls also generally takes a disproportionate over-focus on the 'melodrama' of family life (Puwar 2003; Ahmad 2003), where issues of stringent marriage practices, cultural norms, lack of agency and strict parenting continue to be main topics within academic research (Gill and Anitha 2011). The discourse of 'between two cultures' refers to the positioning of second generation migrants experiencing a conflict of identities due to exposure to diverse sets of values and expectations from the distinct worlds of the home, family and ethnic community on the one hand, and wider British society on the other (Ghuman 2003; Watson 1977). Ghuman (2003) contends that the home school dichotomy for South Asian girls is particularly heightened because the liberal gender equality that the school advocates stands in contrast to the heightened patriarchy in South Asian culture. Girls have the 
added responsibility for upholding cultural rules such as the izzat or 'honour' of the family, resulting in heightened regulation and surveillance from parents because of fears of Western society compromising their daughters' alignment to their familial cultural norms.

In the contemporary British context of 'race' relations, being 'between two cultures' is posited as a key feature of the backlash against multiculturalism and the problems associated with South Asians and Muslims due to the incompatibility of their values and lifestyles with British values (Kundnani 2012). South Asian girls continue to be constructed in media and policy discourse as in need of saving from backward traditions such as 'honour' violence and forced marriage (Shain 2010), oppressive expressions of religious belief, such as veiling (Housee 2004; Mirza 2009), and more recently as jihadi brides in Syria (Saltman and Smith 2015; Mirza 2015). South Asians are typically positioned through binary discourses of 'East' and 'West', and the girls represented through the dichotomies of civilised/uncivilised, traditional/modern, oppressed/ liberated, and the veiled/unveiled woman.

The schooling context has been identified as a key site in which such discourses play out. Teachers have been found to draw on culturally reductionist interpretations of South Asian and Muslim girls and their families, consonant with the 'between two cultures' thesis (Meetoo 2016). South Asian parents have been positioned as having low aspirations for their daughters because of early marriage, leading to low professional aspirations and minimal educational support and investment in the girls' career trajectories (Bhatti 1999; Basit 1997). They have further been positioned as separatist, not mixing with other families, lacking involvement in the school, and preventing their daughters from participating in school trips and extra curricula activities such as school proms and concerts (Crozier and Davies 2007; 2008; Crozier 2009).

\section{A challenge to 'between two cultures': South Asian girls' intersectional identities}

In response to these stereotypes, a significant body of scholarly work on South Asian and Muslim girls in the UK has challenged such reductionist representations. Studies on South Asian girls' identities are largely informed by an understanding that 
identities are intersectional, that 'race' or ethnicity are not a substantial unit of analysis in themselves to understand social positions, nor the processes of social positioning. Intersectionality informs analyses of identities by evidencing inequalities (Verloo 2006), and by offering a more nuanced understanding of the complexities of how subjects are marginalised through the interrelationship between different identity categories. Macro interlocking structures and micro lived 'everyday' experiences are brought together (Bilge 2010; Mirza 2013), with the opportunity to map the affect of gendered and 'raced' discourses through the bodies of subjects (Mirza 2013). It is through intersectional identities that links can be made between 'everyday', micro social processes and macro structural organisation. Intersectionality then, can be a tool to explore everyday experience through intersecting identity categories, locating analyses beyond the mono-dimensional analytical category of 'race' to understanding how 'race' is constituted through gender and class, and vice versa, functioning through an interplay in the production and reproduction of social inequality (Bilge 2010).

Studies that employ an intersectional approach have been useful in troubling the dichotomous representations of Western and Eastern women, offering a more nuanced understanding of Muslim women's agency in veiling (Dwyer 1999; Afshar 2008) and representations of Asian marriages as bogus, arranged and forced (Ahmad 2012; Gill and Anitha 2011). They highlight the role of young women and girls as active negotiators in shifting marital expectations (Bhopal 2011a; Pichler 2007), schooling identities (Shain 2003; 2010; Ludhra 2015), and educational attainment and social and 'ethnic' capital (Bagguely and Hussain 2014; Bhopal 2011b) and in so doing shift the focus from cultural pathologisation and victimization from patriarchal families to agentic practice. These studies have invaluably increased understanding of the links between attainment, identities, discourse and agency, and focus on themes of culture and difference (e.g. through marriage and shared ethnic identities such as Indian or Gujarati), familial relations and 'values', such as theories of 'ethnic' capital where cultural values are prioritised to explain educational attainment (Shah, Dwyer, and Modood 2010).

\section{Positioning South Asian Muslim girls in the multicultural backlash}


Multiculturalism features in scholarly work and political commentaries as a contested and blurred term. It has been referred to as a state or ideological concept that includes top down policies and political spin (Howarth and Andreouli 2013), and cultural plurality itself (Gilroy 2004; 2012). However, multiculturalism is generally referred to as a political and policy response to govern and manage multi-ethnicity created by immigrant populations (Rattansi 2011), an issue of 'managing' and responding to diversity (Ahmed 2009), and state multiculturalism is generally associated with the acknowledgement of cultural pluralism and the promotion of cultural variety.

Young British Muslims, the majority of whom are also of South Asian descent, are predominantly represented in dominant governmental and media discourse as examples that multiculturalism has failed (Harris 2013), and as the 'Other' that is most threatening to British society (Modood 2005a). Numerous key events associated with radical Islam have given rise to this, such as the terrorist attacks in New York and London. The disturbances in the Northern British towns of Bradford, Burnley and Oldham in 2001, which involved clashes between Asian and white youths, were understood to be indicative of the separation and 'parallel lives' of white and Asian residents (Cantle 2001). A more recent government report on integration and extremism highlights the parallel lives amongst different ethnic and religious communities, suggesting that immigrants and children in schools should be encouraged to embrace 'British values', that the English language be promoted and social mixing among young people encouraged. For South Asian and Muslim women, the report suggests securing "women's emancipation in communities where they are being held back by regressive cultural practices" (Casey 2016). Multiculturalism has been in part blamed for promoting self-segregation through its celebration of diverse cultures, which is seen to encourage separatism rather than shared national identities. Official state discourse as represented in such reports posits multiculturalism as perpetuating a lack of integration and ethnic minority people living parallel, rather than shared lives (Kundnani 2012; Kymlicka 2012; Modood 2005b), and for fostering diversity that is out of control (Lentin and Titley 2012).

Further criticisms of multiculturalism have also featured in some feminist debates about the negative effects of multicultural discourses on gender equality for minority 
ethnic women. South Asian women and girls feature strongly in this literature, which details how multiculturalism's 'respect for difference' fosters non-intervention in gender inequalities. For instance, Patel (2007) found that South Asian parents tended to withdraw their daughters from residential trips and other mixed gender activities, even when these were 'essential' to their studies (see also Crozier and Davies 2007). Teachers' lack of will to challenge Asian parents was a result of their respect for cultural difference, which was fostered by the multicultural approach the school adopted. Most feminists critiques of multiculturalism address gender based violence, arguing that multicultural approaches have been deemed largely 'gender blind' (Okin 1998; Phillips 2007), leading to the needs of minority ethnic women being neglected (Burman and Chantler 2003; Puri 2005). Such work highlights how the emphasis on respect for diversity and cultural difference can unwittingly influence professional non- intervention in domestic violence, and reduced sentencing when such acts are is seen to be rooted in cultural and religious practices. Multicultural paralysis has been found to be particularly pronounced for South Asian women and girls deemed at risk from patriarchal belief systems of 'honour and shame' (Wilson 2006).

More recently, Western states have witnessed terrorism carried out by 'home-grown' Muslims (i.e. those born and raised in Western Europe) and have been grappling with the involvement and recruitment of Western born Muslims in the Islamic State (Isis) ${ }^{1}$. Muslim girls, some of whom are of school age, have been recruited as 'Jihadi Brides' to join Isis in Syria (Saltman and Smith 2015). The discourse on the failure of multiculturalism positions a significant proportion of Muslim girls who are also typically of South Asian descent (i.e. Bangladeshi and Pakistani) as the Others within, as symbols of fundamentalism, terrorism and victims of religious and cultural oppression. South Asian and Muslim girls remain a prominent focus of the British multicultural landscape as troubled subjects and in need of being 'managed'. This heightened visibility and hostility towards Muslims has been found to have an effect on how young Muslims are positioning themselves, particularly as a product of the interaction between wider discourses with everyday practices of school, culture, and home (Haw 2009; 2010; 2011). External political and global changes have increased

\footnotetext{
${ }^{1}$ Isis refers to the Islamist militant group that has ceased parts of land between Syria and Iraq.
} 
young Muslims' visibility, who in response, have reasserted their Muslim identity by preferring to describe themselves by their religious global identity rather than ethnicity in a hostile and racist environment (Housee 2004; 2010; Valentine and Sporton 2009; Hoque 2015). This newer body of research on new Muslim identities attempts to situate the self within shifting processes of racialization in the British multicultural context (Hamid 2017).

\section{Towards Multiculturalism as 'everyday': the analytical frame}

There has been growing interest in conceptualising multiculturalism as the 'fact' of diversity itself, along with a focus on everyday meanings of living together (Gilroy 2004; 2012; Ho 2010; Harris 2013; Howarth and Andreouli 2013). As an early proponent of this approach, Hall (1999) talked about the notion of 'multicultural drift' rather than multiculturalism as policy. Multicultural drift was coined to capture the increasing visibility of 'natural' participation of minorities in the streets as an inevitable part of British life. Similarly, 'everyday' multiculturalism is an approach to understanding the everyday dimensions of multiculturalism as it is lived (Wise 2014), whereby different ethnic groups exist alongside one another. Therefore, everyday multiculturalism sits in contrast to top down state multiculturalism, as it focuses on how ethnic mix is experienced and negotiated in everyday situations such as diverse neighbourhoods, schools and organisations (Wise 2014).

The negativity and backlash towards multiculturalism has been challenged by a number of scholars in a move to conceptualise multiculturalism as 'everyday' (Gilroy 2004; Harris 2013; Wise 2014). A focus on the 'everyday' experiences and the lived realities of multiculturalism responds to the pressing need of addressing how we can live with difference so that British 'multiculture' can be celebrated without anxiety and fear (Gilroy 2004). In this article, the notion of multiculturalism as 'everyday' in the school is taken up as a way forward from the culture trap and reductionism that is arguably of particular significance for South Asian Muslim girls given negative representations of 'culture' and tradition as oppressive. This article discusses how the girls were positioned by others, and positioned themselves in everyday multiculturalism, in light of the school's ethnically diverse student population, and what this meant for the production of difference through everyday encounters. The 
school is used as a case study, a 'micropublic' for everyday multiculturalism where students are compelled to negotiate with each other, potentially transcend cultural boundaries, and where identity negotiations take place (Amin 2002; Ho 2011).

According to Harris (2013) 'everyday' multiculturalism is in ordinary social spaces in which people of different backgrounds encounter one another, and consists of the mundane practices they construct and draw on to manage these encounters. This implies that everyday multiculturalism is dynamic and a lived field of action in which social actors construct and deconstruct ideas of cultural difference, national belonging and place making. The 'everyday' in multiculturalism can be a descriptive and analytical frame to shift the focus from fixed notions of ethnic groups and their culture, towards places and practices that produce and rework ethnic and cultural identifications through mixed encounters, conflict and negotiation. Crucially, everyday multiculturalism can bring to light micro projects where production and contestation of cultural difference and values occur through everyday practices and encounters (Harris 2013).

\section{The study: South Asian (Muslim) girls' identities in an everyday multicultural school context}

Fieldwork for this three-year case study took place between 2008 to 2011 at 'Hillside' secondary school, a mixed sex inner city comprehensive school in England with approximately 850 secondary students, and 100 sixth formers. According to the school's Ofsted report in 2008, a high proportion of its students were eligible for free school meals. Three quarters of students were from minority ethnic groups, with a third from Black African or Black Caribbean backgrounds. South Asian students were in the minority and classified under 'other ethnic groups' which constituted a third of the school's ethnic minority student body. The student participants on which this article reports, consisted of nine girls who self-identified as South Asian. Six of the girls also identified as Muslim. Unlike the majority of South Asian children in UK schools who are 'second' or 'third generation' migrants, all but one of the South Asian girls involved in this study were 'first generation' migrants (i.e. born abroad).

Seven focus groups were held with the nine girls during Personal Social Health and Citizenship Education (PSHCE) lessons during the first three months of data 
collection. The girls were in Year 11 (age 15-16) when the focus groups were conducted. Loose topics to initiate discussion were set including feelings of belonging, friendship, racism, and educational aspirations. Written exercises were used in the final session where the participants were asked to write about their experiences in the school. Two focus groups were also conducted with groups of mixed ethnicity, female students in the same year, and were similarly conducted during PSHCE classes. These groups each consisted of ten girls from a mixture of minority ethnic backgrounds, some first-generation migrants from Asia, Africa, the Caribbean and Eastern Europe, and second-generation migrants from South Asia and the Caribbean. The mixed focus groups aimed to capture sentiments about the school's multicultural context and the multicultural dynamic to understand their views on diversity, racism and other issues that the students identified as characterising their school experiences (Ali 2003).

Lastly, multiple interviews were conducted with eight of the South Asian girls who also participated in the focus groups over the three years spent at Hillside. Vrinda was not interviewed as she left the school after the focus groups were conducted. The girls were interviewed over lunchtime for one hour. The initial intention was to interview each of the girls three times over the three years, but as circumstances changed for some of the participants, this was not possible. To explore the meanings of education, home, popular culture and gender relations for the girls, a semistructured approach was used.

Table 1: South Asian student participants at Hillside

\begin{tabular}{|l|l|l|l|l|l|}
\hline $\begin{array}{l}\text { Student } \\
\text { name }\end{array}$ & $\begin{array}{l}\text { Country of } \\
\text { origin }\end{array}$ & $\begin{array}{l}\text { Born in } \\
\text { UK }\end{array}$ & $\begin{array}{l}\text { Year } \\
\text { entered } \\
\text { UK }\end{array}$ & Religion & $\begin{array}{l}\text { No of times } \\
\text { interviewed }\end{array}$ \\
\hline Zara & Afghanistan & No & 2006 & Muslim & 6 \\
\hline $\begin{array}{l}\text { Meena } \\
\text { Zara's twin) }\end{array}$ & Afghanistan & No & 2006 & Muslim & 3 \\
\hline Jamila & Afghanistan & No & 2003 & Muslim & 3 \\
\hline Halima & Pakistan & Yes & N/A & Muslim & 3 \\
\hline Nasreen & Pakistan & No & 2006 & Muslim & 2 \\
\hline Raani & Pakistan & No & 2006 & Muslim & 2 \\
\hline
\end{tabular}




\begin{tabular}{|l|l|l|l|l|l|}
\hline Gargi & India & No & 2006 & Hindu & 4 \\
\hline Vrinda & Mauritius & No & N/A & Hindu & $\begin{array}{l}\text { Not } \\
\text { interviewed } \\
\text { (student left } \\
\text { the school) }\end{array}$ \\
\hline Asanka & Sri Lanka & No & 2007 & Hindu & 2 \\
\hline
\end{tabular}

All the girls spoke English with different levels of fluency. With the exception of Gargi, the more recent migrants, Raani, Nasreen, Meena, Zara and Asanka, had lower levels of English ability and were receiving English language support during lessons. They did not require translators and were able to understand, and take part in, discussions. All interviews and focus groups were recorded and transcribed verbatim and names have been pseudonymised. Teachers were also interviewed as part of the study, findings for which are reported elsewhere (Meetoo 2016; 2018).

Ethical clearance was obtained from the Institute of Education ethics committee.

\section{Positioning the researcher: a 'South Asian' woman doing research with 'South}

\section{Asian' girls}

Being positioned as a 'South Asian' woman by the main gatekeeper, and as a university student-researcher and a mother was an asset to facilitating the researcher's access to the school. The gatekeeper, a white female teacher who was head of the Ethnic Minority Achievement Department, had a desire to understand more about the home lives of this group of girls, some of whom were also struggling academically. The researcher was positioned by the teacher as someone who could tap into the girls' experiences and also act a potential 'role model' for the girls, as an 'example' of pursuing multiple pathways and educational aspirations (Meetoo 2016; 2018). Whilst there were many differences beyond age and generation such as social class background, migratory pathways, and religious and ethnic identification (the researcher is of mixed heritage background), there were also a shared a number of experiences including being racialised, marginalisation and experiences of patriarchal practices at home. Sharing experiences of racism, and minority status had a significant bearing on the research process (Egharevba 2001). These perceived commonalities expressed on numerous occasions in the focus groups and 
interviews enabled the researcher to present herself as an insider, which appeared to positively influence rapport with the participants. For instance, when talking about home life and relationship with parents, some of the girls explicitly stated that the white teachers did not understand them, and in contrast felt that the researcher did. In addition, having 'South Asian girls only' spaces for focus group discussion during PSCHE lessons appeared to provide a comfortable space. Therefore, same 'race' identification facilitated dialogue and opened up other non-threatening spaces that enabled some experiences to be shared (Housee 2004).

\section{Findings}

\section{South Asian girls in contradictory processes of racialisation in 'everyday' multiculturalism}

\section{The warmth of diversity vs exclusions}

'Everyday' multiculturalism was experienced by the girls as highly contradictory. On the one hand, it was commonly interpreted as 'warm' and welcoming, but on the other, the girls' experiences indicate that exclusionary experiences based on processes of Othering. Their narratives of 'everyday' multiculturalism mirrored a 'happy' discourse surrounding ethnic mix and the consumption of different cultures, where constructions of multiculturalism as a 'gift' were taken up (Ahmed 2009). However, as racialised subjects they negotiated ethnic allegiances to manage being excluded. In the absence of a discourse on 'racism' and behind the façade of 'warm' 'everyday' multiculturalism, subtler versions of 'race' and racism circulated that mark the girls' 'everyday' experiences.

The idea that the school was multicultural because of its ethnic diversity was a shared sentiment amongst the South Asian girls and the girls in the two mixed focus groups. The 'variety of cultures' (Focus group 3), and 'all different backgrounds, religions, different cultures and ...different languages' (Mixed focus group 1) were taken to be indicators of multiculturalism. Pupils in the mixed focus groups were largely positive about the school's diversity, which they saw as an asset to the school environment and their learning. One discussion indicated that pupils saw 'everyday' multiculture as reducing the likelihood of racism in the school:

Int: So do you think this school is multicultural? 
Pupil 1: Yeah.

Pupil 2: I think it's a good thing, because you really get to learn about other people's backgrounds and cultures

Pupil 3: Also unlikely for racism. What's the word? OK, people are going to be less racist because there are so many different backgrounds, so it's not like a school that had one race and then a few different races (Mixed focus group 1)

The presence of multicultures was viewed as facilitating students to 'get on', but also learning about difference was seen as a given sequitur to reduce racism. The school's ethnic mix gave the students a sense of 'warmth' and a 'happy' diverse school space (Ahmed 2009).

Such warmth was reflected in the girls' narratives about the welcome and promise of multiculturalism as a positive feature of their schooling. As Gargi explained, ethnic diversity was a driver in her mother's decision to move the family to London. In the following extract, she contrasts the village feel of the Welsh town with a vibrant and multicultural London, the latter of which is seen as offering a better education. Her mother's perception of the multicultural city as progressive and offering more opportunities was a strong factor in determining their move:

My mum said - OK, I will bring you. But when she was in Wales she didn't brought me, because Wales is kind of villagey, so really there is not that good education, and moreover there wasn't any multicultural society over there, only British. So when she came here, in London, for a job in a nursing home, she settled herself here, and she called me and my dad (Gargi, first generation, India, Interview 1).

The 'promise' of multiculture was a door to opportunities and a better life. 'Everyday' multiculturalism was something to be consumed to increase educational prospects and opportunities. The data suggest the girls bought into the ideal of multiculturalism but their everyday realities signalled something different.

The everyday multicultural context of the school was ridden with a significant contradiction that appeared to stem from processes of ethnic exclusion. Although not 
all the girls in this study would typically be classified as South Asian, such the participants from Afghanistan, they talked about friendship groups predominantly as formed of 'Asian girls', and offered reasons for this based on experiences of exclusion from other students. Their stories were marked by experiences of tension and marginalisation based on 'race', which stood in contrast to their perceptions of benefits of 'warm' 'everyday' multiculturalism. When I asked Zara who she was friends with, she replied:

Mostly my sister, Gargi and the girls from Pakistan like Nasreen and that's it. I don't hang around with white people cos they don't want me to hang around with them, so they just leave me. I prefer people that like me (Zara, Afghani, first generation migrant, interview 2)

Jamila similarly explained that she was not accepted by many of the other pupils, which led her to align herself with pupils 'like her'. However, this alignment was not only about a shared sense of culture and religion, but also experiences of being excluded by others. The girls strategically positioned themselves as 'Asian' (e.g. referring to themselves as the 'Asian gang' during informal conversation) and created a safety zone through a shared identity in reaction to being excluded. This contradiction in the warmth of multiculturalism potentially signifies how 'everyday' multiculturalism as positive and welcoming is a discourse that the girls took up, but did not always reflect their day to day experiences. Friendship groups were formed as allegiances in response to cases of conflict and exclusion by other pupils, (Tatum 2003; Pettigrew 2011).

Conflict and disharmony within 'everyday' multiculturalism has similarly been highlighted in Harris's (2013) study of young people in Australian cities. Harris suggests that multicultures are always incomplete, and that conflict and exclusionary processes between ethnic groups are part and parcel of 'everyday' negotiations alongside forms of mixing and hybridity (p143). Such exclusions are inevitable as young people and teachers may absorb dominant discourses and delimiting ideologies on national identity and stranger-ness. Young people may also at times find the pull of singular inter-ethnic interpellations to be irresistible (Gest 2014), resulting in friend/enemy divisions (Harris 2013). The South Asian girls at Hillside 
strategically negotiated racialised exclusions by forming their own ethnic allegiances, which in the process reified ethnic boundaries and created new, shared ethnicities (Hall 1996).

\section{Bullying, new migrants and the silence of racism}

Processes of exclusion were also evident in the girls' experiences of being bullied, but their stories were not articulated within the realms of ethnic categories (e.g. Pakistani, Indian) or being Muslim. Perhaps somewhat unexpectedly given the antiIslamic climate (Kundnani 2012; Hoque 2015), none of the girls spoke about being bullied because they were Muslim, or for wearing the hijab. Instead, being bullied was explicitly linked to their experiences as newly arrived migrant pupils. This suggests that being migrant within the school's everyday multiculturalism appeared, at least on the surface, to matter more than 'race' or religion as an exclusionary category of difference. According to Jamila it was predominantly 'white (English) girls who would pick on the new kids who didn't know English'.

However, the following examples indicate that bullying was also laced with racialised and gendered connotations. Having had 'high' status amongst her peers in India, where she was seen as 'pretty and clever' (Interview 1), Gargi spoke about how this status dramatically changed on arrival at Hillside:

And so they used to tell me - you just came from India, how could you be in the top set right now? ....in English...there was this boy who was asking me - so you are in the top set...do you know where you live? Asking me these stupid questions. And also when I was in geography they were making fun of my religion, because they say, you know, the elephant god, he has got an elephant face, and they were making fun of that as well. I just remember one of the boys, he used to touch me wherever he wants, and I didn't used to like that, because I came from a girls' school...so it was a bit difficult for me to get into this school (Gargi, Interview 4).

Like the others who arrived as new migrants, Gargi was teased in class for having a different accent. She also experienced having her learning abilities questioned, her religious identity ridiculed, and sexual bullying through touching and mocking of her 
physical appearance (i.e. curly hair). Her account suggests that she was victimised by other pupils primarily because she was a new arrival, but also fuelled by her embodiment of the intersections of 'race', religion, and gender (Mirza 2013).

Nasreen was also bullied as a new arrival, and her experiences appeared to be marked by racist and gendered taunting, (e.g. having her hijab pulled, being chased because she wore a scarf, and being called Paki:

I moved on to a new country when I was 11 years old. I'm from Pakistan and when I came to England I couldn't be able to speak English. And by the time I start school I was in Year 8. I was so scared, confused because this school and this country was completely new for me. And all my classmates was so rude to me and they used to call me 'Paki'. I used to hate when they get rude to me, and annoying me. I used to feel angry and also I wear a scarf and people in my class used to chase me because of my scarf. But when I was in Year $10 \mathrm{I}$ had lots of friends and the people who used to get rude to me they are so nice to me. They think I am funny (Extract from written exercise).

Nasreen went on to explain how she had retaliated against the bullies and often got into fights (Interview 2). In comparison to Gargi, she had lower levels of English language competency on arrival in the UK, which she cites as a reason for being bullied. These two examples highlight the complexities in articulating forms of bullying because of the girls' intersectional subject positions and the multiple ways in which they were positioned. There were clear elements of racial bullying through the use of language such as 'Paki' and ridicule of religion, but this was more pronounced on arrival because of their subject positions as new migrants. The girls did not articulate their experiences as racism or racist bullying, nor sexual bullying. Their position in the school as relatively new migrants may have arguably limited their access to language to articulate such experiences of racism. However, Halima, a second generation migrant born in the UK similarly minimised the significance of racism in her everyday experiences, attributing being teased to her 'physical appearance'.

In their study of young Somalis, Valentine and Sporton (2009) similarly found that racism was not articulated, but instead referred to as 'bullying', despite participants 
recounting being called 'black bastard'. As the girls in this study, the young Somalis adopted the language of warm 'everyday' multiculturalism to describe their encounters, without reference to the significance of skin colour. Both these findings resonate with what Harries (2014) sees as the increasing absence of a language to talk about 'race' and therefore racism, and multicultural 'warmth' overshadows racism. The absence of the language to talk about 'race' can similarly be found in wider policy discourse, which she argues trickles down to the 'everyday' context in which subjects are no longer given the tools to engage with 'race'. The silencing of 'race' and therefore racism is compounded in cosmopolitan environments characterized by warm, tolerant, and happy 'everyday' multicultural discourse, carrying significant implications for articulating experiences of racism and also sexism in educational contexts and processes of Othering.

\section{South Asian Muslim girls' constructions of Otherness in everyday multicultural encounters}

\section{Relational identities}

Some of the girls at Hillside constructed ethnic identity through relative racialised differences, defining what they were not in comparison to other students. These constructions were based on what they saw as positive characteristics of being South Asian as opposed to the negative differences they perceived to characterise other groups (Said 1978), denoting a form of reversed racialised Othering. Families featured as one defining feature of relative difference, and in particular, white British families who were seen negatively 'distinct' from Asian families. When I asked Asanka how her life was different to the other children she commented:

Because they (the English) have loads of, you know, they have loads of different fathers, different mums, I am really sorry to say this, because they have more than one mum, more than two dads, like that, and they have a lot of boyfriends as well, and everything with them is like that. But I have got one dad, one mum (Asanka, Interview 1)

Asanka's narrative suggests that English families are likely to be more chaotic because of parental relationship breakdowns, new partners and a higher number of partners before marriage. This is in contrast to how she sees her own family, as 
stable with 'one dad, one mum'. Similarly, Gargi talked about being raised differently to the English and also black (African Caribbean) children in the school:

I respect my parents and my culture. English students, English people, English kids don't. They don't respect no-one. Because we are taught in a way, we are socialised in a way that we should respect our elders, but these people don't, so that's the main difference between me and them. I am seeing very rare students who respect their elders... and the black kids, they are really aggressive. I am not aggressive. I have seen, all the black kids I have seen, are aggressive. Every time small things happen they just jump on fighting, they never think that we can solve a situation by talking, rather than getting physical. (Gargi, Interview 3)

Asanka and Gargi's constructions of their ethnic identity suggest that racialised subjectivity is formed through Othering, through distancing oneself from what or who they are not (Brah 1996; Hall 1999, 1996). They articulated being South Asian in relation to 'positive' cultural characteristics that sat in contrast to positioning English families as dysfunctional because of remarriage, multiple parents and boyfriends, echoing Ali's (2003) assertion that culture is the basis for all forms of ethnic identification (e.g. language, religion, dress and clothing), but too can fall foul of the process of racialization' (272). Further, there were biological racialised discourses present in Gargi's reference to black students as naturally physically aggressive (Gillborn 1990; Mac an Ghail 1997; Rollock 2007).

The above examples offer an insight into the persistent presence of older racialised categories in our 'warm' everyday multicultural spaces. At Hillside, the harmony in ethnic diversity appeared alongside narratives of tension and exclusion, and the appreciation of multicultures ran in tandem with old racialised stereotypes. The following section addresses a further hierarchy amongst the messiness of everyday multiculturalism in the school -between and within the South Asian and Muslim girls.

\section{Muslim girls and hierarchies in everyday multiculturalism}

Meanings of being Muslim featured prominently during discussions and interviews, for both the Hindu and Muslim participants. Discussions about being Hindu were 
however, absent. The strong presence of a female Muslim identity was somewhat expected given the current climate in which wider attention on Muslim girls is particularly heightened. Being Muslim was a topical and a visible embodiment of difference (e.g. through religious dress), and due to a number of spontaneous discussions about being Muslim, it appeared as though the girls felt they were expected to talk about their religious identity.

The Muslim girls were under scrutiny and faced questioning from other girls in the group about their faith. One such symbol of Otherness has been largely denoted through the wearing of the hijab, which has become a symbol of Muslim women's oppression, radicalism, extremism and terrorism (Mirza and Meetoo 2013; Harries 2014). During one focus group the girls' exchanges were laced with discourses on Otherness and undesirable femininity, where they appeared to be navigating different discourses between home, media representations, teacher concerns and challenges from peers within the school:

Nasreen: wearing the hijab, yeah, symbolises gangster

Meena: they have got bomb underneath! (lots of laughter)

Nasreen: some people think there might be a man in there

Int: what else? Why do you girls wear it?

Raani: because we are Muslim

Nasreen: because I like it and it's comfortable

Zara: you hide your ugliness!

Halima: modesty

Zara: no miss, in my heart I am Muslim. I am not showing it like her...they dress in pyjama! They say they wear the pyjama underneath!

(lots of laughter)

Int: what about this image?

[I show them an image of an older woman in a hijab]

Halima: that's in Pakistan

Gargi: Is it a boy?

Halima: No it's a lady

Gargi: She has to do her eyebrows

Nasreen: hello. We are talking about the hijab, not her 
Nasreen: that's what I did miss yeah, when I went to Pakistan yeah. This is me yeah, I was wearing the Shalwar Kameez

[Nasreen wraps her face with scarf so can just see her eyes]

Halima: cos you have to cover yourself from the men over there

Nasreen: cos there yeah people look at me so I did it like that

Gargi: don't you feel hot in it?

Meena: no...head lice!

Zara: You smell your own mouth! Oh no, virus on my scarf!

Nasreen: and then I wear like long thing

Zara: are these women hiding their identity?

Gargi: why are they hiding their identity?

Halima: from men! So you don't get stared at by other people

Zara: They might be not pretty!

Gargi: It's not like the man will rape them in front of everyone is he? Then why is the lady hiding? Cos now yeah when we three are walking, there are three girls who wear like them only but are covered everywhere and they become centre of attraction rather than us lot. They are actually making themselves the centre of something (Focus group 7)

The above dialogue contains a number of themes that relate to the wider negative discourses on the Muslim Other within, specifically as terrorists, dangerous citizens (Haw 2010; Kundnani 2012). As found in populist media reporting, the idea that the veil is used as a means to conceal terrorist identity, that the women have something to hide, was taken up by a number of the girls. Gargi argues that by wearing the veil, more attraction is being drawn to oneself, by which place themselves at the centre of negative attention and actively mark themselves further as outsiders.

Parts of the discussion were also marked by notions of desirable femininity, which were based on religious and racialised difference. Veiled Muslim women were positioned as the Others of desired beauty and open to ridicule (e.g. she needs to do her eyebrows, head lice, and hiding ugliness). Despite the humorous atmosphere 
during the discussion, it was noteworthy that critics of the hijab (Gargi, Zara and Meena) constructed the other girls who did wear the hijab as Others despite there being more girls in the room who veiled than those who did not. The girls who veiled were verbally challenged as potentially having something to hide, as terrorists or lacking 'desirable' beauty, and further suggests that there was a hierarchy amongst the girls based on veiling.

Constructions that are commonly found in dominant negative representations of Muslims in the UK were alive in the girls' narratives and appeared to influence the ways in which the girls positioned one another within their ethnic and religious enclaves. The girls disciplined each other in light of wider racialised and gendered stereotypes and expectations, keeping ethnic and racialised boundaries in check and reinforcing negative meanings attached to being Muslim.

\section{Conclusions: South Asian and Muslim girls' identities in a 'post-race' everyday multicultural context}

This article has highlighted the identity making and social positioning processes in an everyday multicultural school context for South Asian and Muslim girls. Spurred by a yearning to move beyond the 'between cultures lens' and the melodrama of family life, the analytical lens of everyday multiculturalism has highlighted the importance of everyday, mundane interactions in a multicultural school setting in shaping identities through processes of racialisation and gendered positioning.

Claims that we are now living in a 'post' race society, where 'race' is becoming less significant, has been met with academic scepticism (Paul 2013; Nayak 2006). Data from this study supports this scepticism by showing how on the surface, 'race' does not appear to matter due to the marked absence of the language to talk about 'race' and racism. In the context of 'warm and welcoming' multiculturalism, diversity is embraced and seen as an asset to education and city living. When the girls did articulate exclusion, this was primarily done so in relation to being migrant, signalling the 'post race' subject constructing themselves as multicultural citizens, rather than as racialised subjects (Harries 2014: 1120). However, beyond the glossy surface, their daily encounters and experiences were not synonymous with 'warmth' and 
respect for difference, but instead imbued with complex power relations that the South Asian Muslim girls embodied through 'race' and gender.

The warmth of the multicultural school was ridden with contradictions made evident through the presence of old racialised categories. The girls actively shaped their ethnic identities, forming their 'Asian' gang, but they did so within subject positions that were available to them (Valentine and Sporton 2009), as their bodies were interpellated into pre-determined racialised boxes (Phoenix 2009). They drew on facets of their shared 'Asian' identity to articulate experiences of gendered inequalities within the family, and marginalisation and exclusion from other friendship circles. They negotiated ethnic and religious identities as a source of group strength amidst the exclusion they experienced, creating the conditions in which their South Asian and 'Asian' ethnic identities were borne in moments of solidarity and resistance in the school's 'everyday' multiculturalism.

'Everyday' convivial multicultural contexts found in micro-publics such as schools provides an important lens to understand the persistence of racialised and gendered hierarchies. As a lens, it offers a means to explore experiences of South Asian and Muslim girls that move beyond the melodrama of family life, towards how race and gender are reproduced in our everyday contexts (Valentine and Sporton 2009), at specific moments in time, and embodied by young minority ethnic women (Mirza 2013). Teachers, other school staff, policy makers and indeed researchers exploring school experiences should continue to engage with 'race' to negate its presence (Nayak 2006), whilst remaining sensitive to specific gendered inequalities that processes of racialization produce. 


\section{References}

Afshar, Haleh. 2008. 'Can I see your hair? Choice, agency and attitudes: the dilemma of faith and feminism for Muslim women who cover'. Ethnic and Racial Studies, 31 (2): $411-427$.

Ahmad, Fauzia. 2003. '"Still 'in progress?" Methodological Dilemmas, tensions and contradictions in theorizing South Asian Muslim women'. In South Asian Women in the Diaspora, edited by Nirmal Puwar and Parvati Raghuram, 43-65. Oxford: Berg.

Ahmad, Fauzia. 2012. 'Graduating towards marriage? Attitudes towards marriage and relationships among university educated British Muslim women'. Culture and Religion, 13 (2), June: 193-210.

Ahmed, Sara. 2009. 'Embodying Diversity: problems and paradoxes for Black Feminists'. Race Ethnicity and Education, 12 (1), March: 41-52.

Ali, Suki. 2003. Mixed Race, Post Race: Gender, new ethnicities and cultural practices. Oxford: Berg.

Amin, Ash. 2002. 'Ethnicity and the multicultural city: living with diversity'. Environment and Planning, 34 (6): 959-80.

Bagguley, Paul. and Yasmin Hussain. 2016. "Negotiating Mobility: South Asian Women and Higher Education." Sociology 50 (1): 43-59.

Basit, Tehima. 1997. "I Want More Freedom, but Not Too Much: British Muslim Girls and the Dynamism of Family Values." Gender and Education 9 (4): 425-440.

Bhatti, Ghazala. 1999. Asian Children at Home and at School: an ethnographic study. London: Routledge.

Bhopal, Kalwant. 2011a. 'Education makes you have more say in the way your life goes: Indian women and arranged marriages in the United Kingdom'. British Journal of Sociology of Education, 32(3), May: 431-447. 
Bhopal, Kalwant. 2011b. 'We tend to stick together and mostly we stick to our own kind: British Indian women and support networks at university'. Gender and Education, Vol. 23, No. 5, August: 519-534.

Bilge, Silma. 2010. 'Recent feminist outlooks on Intersectionality'. Diogenes, 225: 58-72.

Brah, Avtar. 1996. Cartographies of Diaspora. London: Routledge.

Burman, Erica and Chantler, Khatidja. 2004. 'There's no place like home: Emotional geographies of researching 'race' and refuge provision in Britain'. Gender, Place and Culture, 11(3), 375-397.

Cantle, Ted. 2001. The Cantle Report - Community Cohesion: a report of the Independent Review Team. London: Home Office.

Casey, Louise. 2016. The Casey Review: a review into opportunity and cohesion. London: Department for Communities and Local Government.

Crozier, Gill. and Jane Davies. 2007. 'Hard to reach parents or hard to reach schools? A discussion of home- school relations, with particular reference to Bangladeshi and Pakistani parents'. British Educational Research Journal, 33(3), June: 295-313.

Crozier, Gill. and Jane Davies. 2008. 'The trouble is they don't mix: self segregation or enforced exclusion?' Race Ethnicity and Education, 11(3), September: 285-301.

Crozier, Gill. 2009. 'South Asian parents' aspirations versus teachers' expectations in the United Kingdom'. Theory into Practice, 48: 290-296.

Dwyer, Claire. 1999. 'Veiled meanings: young British Muslims women and the negotiation of difference'. Gender, Place and Culture, 6, 5-26. 
Egharevba, Itohan. 2001. 'Researching an-'other' minority ethnic community: Reflections of a black female researcher on the intersections of race, gender and other power positions on the research process'. International

Gest, Justin. 2014. 'Reluctant Pluralists: European Muslims and Essentialist Identity Structures'. Ethnic and Racial Studies, 38(11), September: 1868-1885.

Ghuman, Paul A. Singh. 2003. Double loyalties: South Asian adolescents in the West. Cardiff: University of Wales Press.

Gill, Aisha and Anitha, Sundari. 2011. 'Introduction: framing forced marriage as a form of violence'. In Forced Marriage: introducing a social justice and human rights perspective edited by Aisha Gill and Sundari Anitha. London: Zed Books.

Gillborn, David. 1990. 'Race', Ethnicity and Education: Teaching and learning in multi-ethnic schools. London: Unwin Hyman.

Gilroy, Paul. 2004. After Empire: melancholia or convivial culture? London: Routledge.

Gilroy, Paul. 2012. "'My Britain is fuck all': zombie multiculturalism and the race politics of citizenship'. Identities: Global Studies in Culture and Power, 19 (4), July: 380-397.

Hall, Stuart. 1996. 'Introduction: who needs identity?'. In Questions of Cultural Identity edited by Stuart Hall and Paul DuGay, 1-17. London: Sage.

Hall, Stuart. 1999. 'From Scarman to Stephen Lawrence'. History Workshop Journal, 48, Autumn: 187-97.

Hamid, Sadek. 2017. Young British Muslims: Between Rhetoric and Reality. London: Routledge.

Harries, Bethan. 2014. 'We need to talk about Race'. Sociology, 48 (6): 1107-1122. 
Harris, Anita. 2013. Young People and Everyday Multiculturalism. New York and London: Routledge.

Haw, Kaye. 2009. 'From hijab to jilbab and the 'myth' of British identity: being Muslim in contemporary Britain a half-generation on'. Race Ethnicity and Education, 12(3), September: 363-378.

Haw, Kaye. 2010. 'The changing same of an in-between generation: negotiating identities through space, place and time'. Discourse: studies in the cultural politics of education, 32(4), October: 565-579.

Ho, Christina. 2011. 'Respecting the presence of Others: School Micropublics and Everyday Multiculturalism'. Journal of Intercultural Studies, 32 (6): 603-619.

Hoque, Aminul. 2015. British-Islamic Identity: third generation Bangladeshis from East London. London: Trentham IOE Press.

Housee, Shirin. 2004. 'Unveiling South Asian Female Identities'. In Institutional Racism in Higher Education, edited by lan Law, Deborah Phillips and Laura Turney. Stoke on Trent: Trentham Books.

Housee, Shirin. 2010. 'When silences are broken: an out of class discussion with Asian female students'. Educational Review, 62(4), November: 421-434.

Howarth, Caroline and Eleni Andreouli. 2013. 'Has multiculturalism failed?' The importance of lay knowledge and everyday practice'. Accessed 10.12.18. https://www.researchgate.net/publication/265275514\%27Has multiculturalism faile d\%27 The importance of lay knowledge and everyday practice

Kundnani, Arun. 2012. 'Multiculturalism and its discontents: left, right and liberal'. European Journal of Cultural Studies, 15 (2): 155-166. 
Kymlicka, Will. 2012. Multiculturalism: success, failure and the future. Washington DC: Migration Policy Institute.

Lentin, Alana. and Gavin Titley. 2012. 'The crisis of 'multiculturalism in Europe: mediated minarets, intolerable subjects'. European Journal of Cultural Studies, 15(2): 123-138.

Ludhra, Geeta. 2015. A black feminist exploration of the cultural experiences and identities of academically 'successful' British South-Asian girls, PhD Thesis, Brunel University.

Mac an Ghaill, Mairtin. 1994. The making of men: masculinities, sexualities and schooling. Buckingham Philadelphia: Open University Press.

Mirza, Heidi Safia. 2009. Race, Gender and Educational Desire: Why Black women succeed and fail. London: Routledge.

Mirza, Heidi Safia. 2013. "A Second Skin': Embodied Intersectionality, Transnationalism and Narratives of Identity and Belonging among Muslim Women in Britain." Women's Studies International Forum 36: 5-16.

Mirza, Heidi Safia. 2015. 'Dangerous' Muslim Girls? Race, Gender and Islamophobia in British Schools'. In The Runnymede School Report: Race, education and inequality in Contemporary Britain, edited by Claire Alexander, Debbie WeekesBernard and Jason. Ardray. London: Runnymede Trust, Accessed 1.10.15 http://www.runnymedetrust.org/uploads/The\%20School\%20Report.pdf

Mirza, Heidi Safia and Veena Meetoo. 2013. 'Gendered surveillance and the social construction young Muslim women in schools'. In (In) equalities: 'Race', class and gender edited by Kalwant Bhopal and Uvanney. Maylor, 126-145. London: Routledge.

Modood, Tariq. 2005a. Multicultural Politics: Racism, Ethnicity and Muslims in Britain. Edinburgh: Edinburgh University Press. 
Modood, Tariq. 2005b. 'Remaking multiculturalism after 7/7'. Open Democracy , 29 September www.openDemocracy.net

Nayak, Anoop. 2006. 'After race: ethnography, race and post-race theory'. Ethnic and Racial Studies, 20(3), May: 411-430.

Okin, Susan Moller. 1998. 'Feminism and multiculturalism: some tensions'. Ethics, 108(4), 661-84.

Paul, Joshua. 2013. 'Post-racial futures: imagining post-racialist anti-racism(s)'. Ethnic and Racial Studies, 37(4): 702-718.

Patel, P. 2007. 'Every Child Matters: the challenge of gender, religion and multiculturalism'. Forum, 49 (3), 261-275.

Pettigrew, Alice. 2011. 'Confronting the limits of antiracist and multicultural education: white students' reflections on identity and difference in a multi-ethnic secondary school'. Sociological Research Online, 17 (3). Accessed 10.12.18.

http://www.socresonline.org.uk/17/3/3.html

Phillips, Ann. 2007. Multiculturalism Without Culture. Princeton, NJ: Princeton University Press.

Phoenix, Ann. 2009. 'De-colonising practices: negotiating narratives from racialised and gendered experiences of education'. Race, Ethnicity and Education, 12(1): 101114.

Pichler, Pia. 2007. 'Talking traditions of marriage - negotiating young British Bangladeshi femininities'. Women's Studies International Forum, 30: 201-216.

Puri, Sunita. 2005. 'Rhetoric v. reality: The effect of 'multiculturalism' on doctors' responses to battered South Asian women in the United States and Britain'. Patterns of Prejudice, 39(4), 416-430. 
Puwar, Nirmal. 2003. "Melodramatic Postures and Constructions." In South Asian Women in the Diaspora, edited by Nirmal Puwar and Parvati Ranghuram, 2142. Oxford: Berg.

Rattansi, Ali. 2011. Multiculturalism: a very short introduction. Oxford: Open University Press.

Rollock, Nicola. 2007. Failure by any other name? Educational Policy and the Continuing Struggle for Black Academic Success. London: The Runnymede Trust.

Said, Edward. W. 1978. Orientalism. London: Penguin.

Saltman, Erin Marie and Melanie Smith. 2015. 'Till Martyrdom Do Us Part': Gender and the ISIS Phenomenon. London: Kings College, Institute for Strategic Dialogue, Accessed 10.12.18.

https://www.isdglobal.org/wpcontent/uploads/2016/02/Till Martyrdom Do Us Part Gender and the ISIS Phen omenon.pdf

Shah, Bindi, Claire Dwyer, and Tariq Modood. 2010. "Explaining Educational Achievement and Career Aspirations among Young British Pakistanis: Mobilizing 'Ethnic Capital'?’ Sociology December 44(6): 1109-1127.

Shain, Farzana. 2003. The Schooling and identity of Asian girls. Stoke on Trent: Trentham Books.

Shain, Farzana. 2010. "Refusing to Integrate? Asian Girls, Achievement and the Experience of Schooling." In Girls and Education 3-16: Continuing Concerns, New Agendas, edited by Carolyn Jackson, Carrie Paechter, and Emma Renold, 6274. Berkshire: Open University Press.

Tatum, Beverly. 2003. Why are All the Black Kids Sitting Together in the Cafeteria?: A Psychologist Explains the Development of Racial Identity. New York: Basic Books. 
Valentine, Gill. and Deborah Sporton. 2009. 'How other people see you, it's like nothing that's inside: the impact of processes of disidentification and disavowal on young people's subjectivities'. Sociology, 43 (4): 735 - 751.

Verloo, Mieke. 2006. 'Multiple Inequalities, Intersectionality and the European Union'. European Journal of Women's Studies, August, 13 (3): 211-228.

Watson, James. 1977. Between two cultures: migrants and minorities in Britain. Oxford: Basil Blackwell.

Wilson, Amrit. 2006. Dreams, Questions and Struggles: South Asian women in Britain. London: Pluto Press.

Wise, Amanda. 2014. 'Everyday multiculturalism'. In Migration: A COMPAS Anthology, edited by Bridget Anderson and Michael Keith. Oxford: COMPAS. Accessed 10.12.18. http://compasanthology.co.uk/wpcontent/uploads/2014/04/COMPASMigrationAnthology.pdf 